\title{
Serologic evidence of Leishmania infection in free-ranging wild and domestic canids around a Brazilian National Park
}

\author{
Nelson Henrique de Almeida Curi/ ${ }^{+}$, Ildikó Miranda*, Sônia A Talamoni
}

\author{
Programa de Pós-Graduação em Zoologia de Vertebrados, Pontifícia Universidade Católica de Minas Gerais, Rua Dom José \\ Gaspar 500, prédio 41, 30535-610 Belo Horizonte, MG, Brasil *Laboratório de Leishmaniose, Fundação Ezequiel Dias, Belo \\ Horizonte, MG, Brasil
}

Transmission of disease between wildlife, domestic animals, and humans is of great concern to conservation issues and public health. Here we report on the prevalence of anti-Leishmania sp. antibodies in 21 wild canids (7 Chrysocyon brachyurus, 12 Cerdocyon thous, and 2 Lycalopex vetulus) and 74 free domestic dogs (Canis familiaris) sampled around the Serra do Cipó National Park. In dogs, the apparent prevalence was $8.1 \%$ and in wild canids it was 19\% (2 crab-eating foxes, C. thous, and 2 maned wolves, C. brachyurus). Management of the domestic dog population with evaluation of incidence changes in humans and wildlife, and enlightenment on the role of wild reservoirs are essential issues for future action and research.

Key words: wild canids - Leishmania - Serra do Cipó National Park

There is increasing concern about disease transmission in the wildlife/domestic animal/human interface. Environmental changes influencing this transmission can be of natural or anthropogenic origin, including human activities expansion, habitat fragmentation, reforestation, climate warming and pollution, and the emergence of diseases also involve biodiversity loss and increasing emergence and incidence of zoonosis (Patz et al. 2000, Daszak et al. 2001).

Leishmaniasis is a zoo-anthroponosis in many areas of South and Central Americas (Silva et al. 2001) caused by species of the genus Leishmania. These flagellate protozoa (Kinetoplastida: Trypanosomatidae) are obligate intracellular parasites of vertebrate hosts, being transmitted by the bite of the sand fly (genus Lutzomyia) (Diptera: Psychodidae: Phlebotominae). The domestic dog is an important reservoir and is responsible for the endemic and epidemic nature of the disease (Silva et al. 2001, Courtenay et al. 2002). Other mammals are natural reservoirs, such as marsupials, rodents (Zulueta et al. 1999), the crab-eating fox C. thous (Lainson et al. 1969, Courtenay et al. 1996, Silva et al. 2000). Crab-eating foxes are commonly infected but rarely infectious or symptomatic, although there are reports of individuals with clinical signs of the disease, which showed spontaneous recovery after showing symptoms (Courtenay et al. 2002).

This study aimed to evaluate seroprevalences for leishmaniasis in three species of free-ranging wild canids [(Chrysocyon brachyurus (Illiger 1815), Cerdocyon thous (Linnaeus 1766), and Lycalopex vetulus (Lund 1842)], and domestic dogs (Canis familiaris) from Serra do Cipó Na-

Financial support: Fundação O Boticário de Proteção à Natureza.

+Corresponding author: nelsoncuri@terra.com.br

Received 24 June 2005

Accepted 16 January 2006 tional Park, and Morro da Pedreira Environmental Protection Area, state of Minas Gerais, South-eastern Brazil.

In the region of study Silva et al. (2001) characterized the parasite as $L$. $(L$.) chagasi ( $=L$. infantum), which is a causative protozoan of American Visceral Leishmaniasis (Grimaldi \& Tesh 1993), and there are reports of the presence of Lutzomyia longipalpis. The region of study borders a large endemic area, the Belo Horizonte metropolitan, in which increasing numbers of human and canine visceral leishmaniasis cases were recorded in the last years. Human cases had also been recorded in municipalities inside the buffer zone, namely Jaboticatubas (Silva et al. 2001), and canine visceral leishmaniasis is reported as common by local health services.

Seven maned wolves, twelve crab-eating foxes, and two hoary foxes were trapped from May to October 2004, and from June to September 2005 in points near two human settlements (Conceição do Mato Dentro municipality and Cardeal Mota district) around the Serra do Cipó National Park (19 $\left.12^{\prime}-19^{\circ} 20^{\prime} \mathrm{S}, 43^{\circ} 30^{\prime}-43^{\circ} 40^{\prime} \mathrm{W}\right)$, state of Minas Gerais, South-eastern Brazil. Seventy-four nonvaccinated free-ranging domestic dogs were sampled from farms and villages near to the capture sites of wild canids. Blood was collected from wild canids under chemical immobilization, and from dogs under physical restraint. Wild canids were anaesthetised using a blowpipe and $3 \mathrm{ml}$ homemade darts with concentrated xilazine chlorhydrate $10 \%$ $(2 \mathrm{mg} / \mathrm{kg})$, and ketamine chlorhydrate $20 \%(8 \mathrm{mg} / \mathrm{kg})$. Blood samples collected from the cephalic vein were allowed to clot for $4 \mathrm{~h}$ at room temperature, and then centrifuged for serum extraction. Serum samples were stored at $-20^{\circ} \mathrm{C}$ prior to analysis. Some drops of whole blood were collected on a filter paper. Serum and filter paper samples were analyzed at Fundação Ezequiel Dias, Belo Horizonte. Immune enzyme assay and indirect immunofluorescence reaction were performed with both materials, using antidog conjugate. Specifity and sensitivity of both tests on domestic dogs are approximately $98 \%$. Values for wild species are unavailable, but the results are reliable since they are phylogenetically related species (Zrzavy \& 
Rickankova 2004). Nevertheless, the data were analyzed as apparent prevalence (Gardner et al. 1996).

We have also performed serological tests using indirect immunofluorescence reaction for Babesia canis with 14 wild canid samples, and the results were all negative (unpublished data). Therefore, we can only exclude this possibility of cross-reaction. Neotropical wild canids are known reservoirs of other protozoa, like Trypanosoma cruzi (e.g. Albuquerque \& Barreto 1968). So, we could not exclude the possibility of cross-reaction with other kinetoplastids.

Results and prevalence are summarized below (see Table). Positive titres were only found at Cardeal Mota, being considered the highest epidemiological risk area for leishmaniasis around the Park. Three of the six positive dogs $(50 \%)$ showed typical signs of leishmaniasis, such as weight loss, skin lesions, and excessive growth of claws, according to Silva et al. (2001). Among the 21 captured wild canids, all of them were healthy and clinically normal, but four animals (19\%) showed positive titres of 40 and 80 . They were respectively a two-year-old female and a four-year-old male $C$. thous, a three-year-old male and a four-year-old female $C$. brachyurus.

Our results are in accordance with other studies that found serologic evidence of Leishmania infection in $C$. thous (e.g. Courtenay et al. 1994). Although it is a confirmed natural reservoir, and many times blamed for supporting the wild and peri-urban disease cycle (see Patz et al. 2000), the crab-eating fox is not important for the maintenance of leishmaniasis, contributing with only $9 \%$ of the transmission, while domestic dogs contribute with $91 \%$ (Courtenay et al. 2002). These authors propose that $C$. thous populations cannot maintain the transmission cycle independently without the presence of domestic dogs, and is improbable that they introduce the parasite into infection-free dog populations. To our knowledge, this is the first study showing serologic evidence of Leishmania infection in the maned wolf (C. brachyurus), and our results indicate that this species might be involved in the leishmaniasis cycle as a wild reservoir. Unfortunately we could not demonstrate the presence of the parasite by parasitological or molecular methods.

Despite the low conservation threat (low mortality or fecundity reduction in wildlife) of leishmaniasis, it may increase susceptibility to other carnivore diseases, and favour their maintenance and transmission in one area.
There is a concern to public health, and it must be investigated in possible wild reservoirs in order to formulate management and control plans. To eradicate the infection, however, measures must be applied on reservoirs (Haydon et al. 2002), in this case, domestic dogs. Courtenay et al. (2002) propose that leishmaniasis control in dogs may result in the decrease of infection rates in sympatric wildlife populations. Additionally, vector control should be part of any intervention strategy in the case of vectorborne diseases. Even human behaviour can influence dynamics of zoonosis, so that hiking, camping, and hunting are activities that represent a risk factor for acquiring diseases from wildlife reservoirs (Kruse et al. 2004). Ecotourism is one of the main economic activities in the region, and public health services must be aware about the possibility of disease introduction or acquirement from tourists. Preventive management and control of the domestic dog population and their contact with wildlife is necessary for the control of leishmaniasis and wildlife diseases in this area. Future research could evaluate changes in human and wildlife incidence, after controlling the disease in dogs.

More studies are necessary to address the importance of wild mammals, subjected to increased habitat loss and fragmentation and to closer human/domestic animal contact, in the leishmaniasis transmission cycle. Diagnostic tools validated for wild species, such as improved and available molecular methods, are also necessary to elucidate the role of wildlife as a source of zoonosis (Kruse et al. 2004), and efforts must be applied to avoid damages or persecution to wild animals, caused by misleading information about their zoonotic potential.

\section{ACKNOWLEDGEMENTS}

To IBAMA - Parque Nacional da Serra do Cipó for logistic help and licenses conceded; to Andrew Linghorn for English revision, and to all habitants of the Serra do Cipó.

\section{REFERENCES}

Albuquerque RDR, Barreto MP 1968. Estudos sobre reservatórios e vectores silvestres do "Trypanosoma cruzi". XXX: Infecção natural do cachorro-do-mato, "Cerdocyon thous azarae" (Wied, 1824) pelo "T. cruzi". Rev Brasil Biol 28: 457-468.

Courtenay O, Macdonald DW, Lainson R, Shaw JJ, Dye C 1994. Epidemiology of canine leishmaniasis: a comparative serological study of dogs and foxes in Amazon Brazil. Parasitology 109: 273-279.

TABLE

Apparent prevalence for leishmaniasis in domestic dogs (CD), wild canids (CS), Cerdocyon thous (Ct), and in Chrysocyon brachyurus $(\mathrm{Cb})$ sampled from May to October 2004, and from June to September 2005, in urban areas around the Serra do Cipó National Park

\begin{tabular}{lcccccccc}
\hline & $\mathrm{CD}$ & Positives & $\mathrm{CS}$ & Positives & $\mathrm{Ct}$ & Positives & Cb & Positives \\
\cline { 2 - 8 } Locality & $\mathrm{n}$ & $(\%)$ & $\mathrm{n}$ & $(\%)$ & $\mathrm{n}$ & $(\%)$ & $\mathrm{n}$ & $(\%)$ \\
\hline Cardeal Mota & 37 & $6(16.2)$ & 17 & $4(23.5)$ & 9 & $2(22.2)$ & 6 & $2(33.3)$ \\
Conceição do Mato Dentro & 37 & 0 & 4 & 0 & 3 & 0 & 1 & 0 \\
\hline Total & 74 & $6(8.1)$ & 21 & $4(19)$ & 12 & $2(16.6)$ & 7 & $2(28.6)$ \\
\hline
\end{tabular}


Courtenay O, Quinnel RJ, Garcez LM, Dye C 2002. Low infectiousness of a wildlife host of Leishmania infantum: the crab-eating fox is not important for transmission. Parasitology 125: 407-414.

Courtenay O, Santana EW, Johnson PJ, Vasconcelos IAB, Vasconcelos AW 1996. Visceral leishmaniasis in the hoary zorro Dusicyon vetulus: a case of mistaken identity. Trans $R$ Soc Trop Med Hyg 90: 498-502.

Daszak P, Cunningham AA, Hyatt AD 2001. Anthropogenic environmental change and the emergence of infectious diseases in wildlife. Acta Trop 78: 103-116.

Gardner IA, Hietala S, Boyce WM 1996. Validity of using serological tests for diagnosis of diseases in wild animals. Rev sci tech Off int Epiz, 15: 323-335.

Grimaldi GJ, Tesh RB 1993. Leishmaniasis of the new world: current concepts and implications for future research. Clin Microb Rev 3: 230-250.

Haydon DT, Cleaveland S, Taylor LH, Laurenson MK 2002. Identifying reservoirs of infection: a conceptual and practical challenge. Emerg Infect Dis 8: 1468-1473.

Kruse H, Kirkemo A, Handeland K 2004. Wildlife as a source of zoonotic infections. Emerg Infect Dis 10: 2067-2072.
Lainson R, Shaw JJ, Lins ZC 1969. Leishmaniasis in Brazil: IV. The fox, Cerdocyon thous as a reservoir of Leishmania donovani in Pará State, Brazil. Trans R Soc Trop Med Hyg 63: 741-745.

Patz JA, Graczyk TK, Geller N, Vittor AY 2000. Effects of environmental change on emerging parasitic diseases. Int $J$ Parasitol 1: 1-11.

Silva ES, Gontijo CMF, Pacheco RS, Fiuza VOP, Brazil RP 2001. Visceral leishmaniasis in the metropolitan region of Belo Horizonte, State of Minas Gerais, Brazil. Mem Inst Oswaldo Cruz 96: 285-291.

Silva ES, Pirmez C, Gontijo CMF, Fernandes O, Brazil RP 2000. Visceral leishmaniasis in the crab-eating fox (Cerdocyon thous) in south-east Brazil. Vet Rec 147: 421422.

Zrzavy J, Ricankova V 2004. Phylogeny of recent canidae (Mammalia, Carnivora): relative reliability and utility of morphological and molecular datasets. Zool Scripta 33: 311333.

Zulueta AM, Villarroel E, Rodriguez N 1999. Epidemiologic aspects of American Visceral Leishmaniasis in an endemic focus in Eastern Venezuela. Am J Trop Med Hyg 61: 945950. 